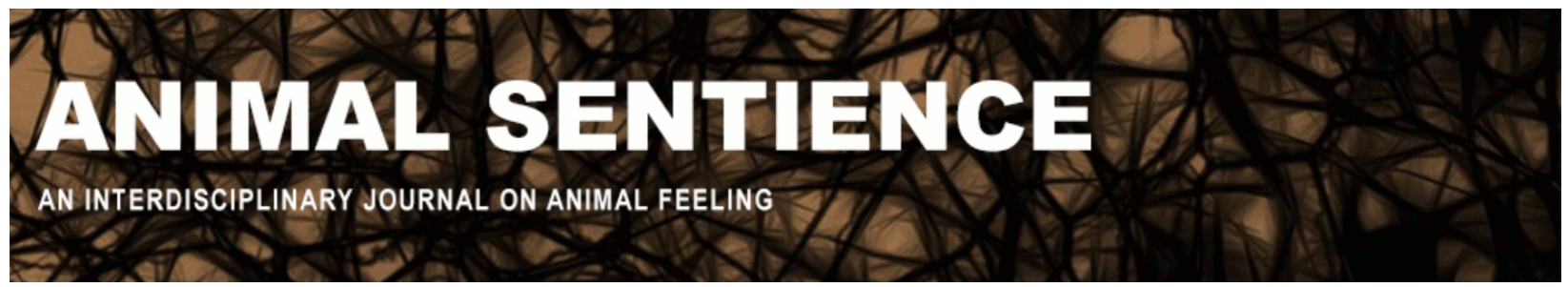

Kopnina, Helen (2019) Anthropocentrism: Practical remedies needed. Animal Sentience 23(37)

DOI: $10.51291 / 2377-7478.1392$

Date of submission: 2019-01-31

Date of acceptance: 2019-02-23

(c)

This article has appeared in the journal Animal

Sentience, a peer-reviewed journal on animal

cognition and feeling. It has been made open access,

free for all, by WellBeing International and deposited

in the WBI Studies Repository. For more information,

please contact

wbisr-info@wellbeingintl.org.

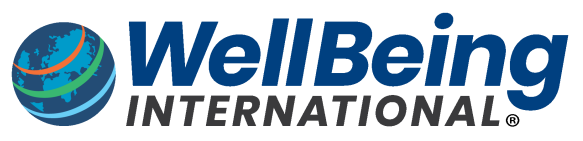

SOLUTIONS FOR PEOPLE, ANIMALS AND ENVIRONMENT 


\title{
Anthropocentrism: Practical remedies needed
}

Commentary on Chapman \& Huffman on Human Difference

\author{
Helen Kopnina \\ Department of International Business \\ The Hague University of Applied Sciences
}

\begin{abstract}
It is true that one of the harmful consequences of creating categories where one group is unique and superior to others is that it justifies discriminating against the inferior groups. And outright abuse of nonhuman animals is indeed morally unjustifiable. But what is to be done about it?
\end{abstract}

\footnotetext{
Helen Kopnina is coordinator of the Sustainable Business program, The Hague University of Applied Science (HHS), Netherlands, and author of over 90 peer-reviewed articles and (co)author and (co)editor of 15 books. She conducts research on environmental sustainability, environmental education and biological conservation. Website
}

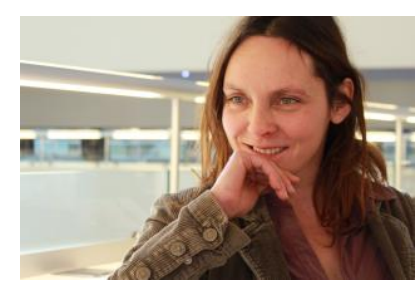

Chapman \& Huffman (2018) (C \& H) are right that human discrimination and outright abuse of nonhuman animals is morally unjustifiable. They also argue correctly that there is nothing intrinsically "better" about the human species to justify our supposed superior status: animals have indeed been shown to outperform humans in many tasks, including cognitive ones. However, C \& H's central question is merely rhetorical. Without even reading their article, a "converted" reader (aware of anthropocentrism, human chauvinism, speciesism, etc.) can already reply that of course the false sense of human superiority is used to justify human cruelty to animals.

C \& H ask: "Why do we want to think humans are different?" The answer is made very clear - because we humans are delusional and use denial to justify atrocities against nature. A real challenge is to provide a new theory or practical advice about how this can be remedied. It is not enough to realize our delusion, as we have recently suggested (Cafaro et al. 2017; Kopnina et al. 2018; Piccolo et al. 2018; Washington et al. 2018). If the challenges of deep ecology (Naess 1973), land ethics (Leopold 1949), animal rights (Singer 1977; Peters 2016), interspecies egalitarianism, or equity (Baxter 2005) are to be taken seriously, some conscious choices will need to be made. Legislating against ecocide (Higgins 2010) or against animal use (Bisgould 2014) might require legal, political, and ethical redefinition of what is just and fair. The planet would need to be divided on the basis of species' natural resource requirements (e.g., Mathews 2016), not on the basis of what one single species proclaims to be its entitlement. C \& H end rather meekly with "We need to acknowledge how much we resemble them and how much we have to learn from them." Yes we do: but how?

How can ecocentrism, deep ecology, eco-democracy, eco-justice, and earth jurisprudence be established in today's dominant human-centered democracies? How can 
animal rights legislation be integrated within mainstream legal systems? C \& H say we need to "to treat animals with the respect they deserve." I suspect that the majority of the readers of this journal, myself included, full-heartedly agree. Yet, without recommendations as to how this "respect" can be practically achieved, the plea sounds helpless and naïve. If C \& H's plea were to reach policy-makers, lawyers, and the public through political action, the media, and education campaigns, this article could add to a great library of work that contributes to and inspires planetary egalitarianism.

\section{References}

Baxter, B. H. (2005) A Theory of Ecological Justice. London, New York: Routledge.

Bisgould, L. (2014) It's time to re-evaluate our relationship with animals.

Cafaro, P., Butler, T., Crist, E., Cryer, P., Dinerstein, E., Kopnina, H., Noss, R., Piccolo, J., Taylor, B., Vynne, C., \& Washington, H. (2017) If we want a whole earth, nature needs half. A reply to half-earth or whole earth? Radical ideas for conservation, and their implications. Oryx-The International Journal of Conservation, 53(1): 400.

Chapman, C. A., \& Huffman, M. A. (2018) Why do we want to think humans are different? Animal Sentience 23(1).

Higgins, P. (2010) Eradicating Ecocide: Laws and Governance to Prevent the Destruction of Our Planet. Shepheard Walwyn Publishers Ltd. 62-63.

Kopnina, H., Taylor, B., Washington, H., \& Piccolo, J. (2018) Anthropocentrism: More than just a misunderstood problem. Journal of Agricultural and Environmental Ethics, 31(1): 109-127.

Leopold, A. (1949) A Sand County Almanac and Sketches Here and There. New York: Oxford University Press.

Mathews, F. (2016) From biodiversity-based conservation to an ethic of bio-proportionality. Biological Conservation, 200: 140-148.

Naess, A. (1973) The shallow and the deep: Long-range ecology movement. A summary. Inquiry, 16: 95-99.

Piccolo, J., Washington, H., Kopnina, H., \& Taylor, B. (2018) Back to the future: Why conservation biologists should re-embrace their ecocentric roots. Conservation Biology, 32(4): 959-961.

Singer, P. (1977) Animal Liberation: A New Ethics for Our Treatment of Animals. New York: Random House.

Washington, H., Piccolo, J., Chapron, G., Gray, J., Kopnina, H., \& Curry, P. (2018) Foregrounding ecojustice in conservation. Biological Conservation, 228: 367-374. 